\title{
Nano Zinc Seed Treatment and Foliar Application on Growth, Yield and Economics of Bt Cotton (Gossypium hirsutum L.)
}

\author{
N. Pruthvi Raj* and C.P. Chandrashekara \\ Department of Agronomy, University of Agricultural Sciences, Dharwad -580 005, \\ Karnataka, India \\ *Corresponding author
}

\section{Keywords}

Cotton, Economics, Foliar application, Micronutrient, Nano zincoxide, Seed treatment

Article Info

Accepted:

12 July 2019

Available Online:

10 August 2019

\section{A B S T R A C T}

A field experiment was conducted at Main Agricultural Research Station, Dharwad, Karnataka, during 2017-18 to evaluate the effect of seed treatment and foliar application of nano $\mathrm{ZnO}$ on growth, yield and economics of $\mathrm{Bt}$ cotton. The experiment was laid out in split plot design with three main treatments $\left(\mathrm{S}_{1}\right.$ :seed treatment with chelated $\mathrm{ZnSO}_{4} @ 4 \mathrm{~g}$ $\mathrm{kg}^{-1}$ seeds, $\mathrm{S}_{2}$ : nano $\mathrm{ZnO} @ 1 \mathrm{~g} \mathrm{~kg}^{-1}$ seeds and $\mathrm{S}_{3}$ :seed priming with $1000 \mathrm{ppm}$ nano zinc solution), four sub plot treatments (Foliar application of nano ZnO @ 500, 750, 1000 and $1250 \mathrm{ppm}$ at square initiation and flowering stage) and three uneven control $\left(\mathrm{C}_{1}\right.$ : $\mathrm{RDF}+$ $\mathrm{FYM}+0.5 \%$ EDTA $\mathrm{ZnSO}_{4}$ foliar application at square initiation and flowering stage, $\mathrm{C}_{2}$ : $\mathrm{C}_{1}+$ seed treatment with $\mathrm{Fe}, \mathrm{Zn}, \mathrm{Mg}$ and $\mathrm{Mn} @ 4 \mathrm{~g}$ each kg ${ }^{-1}$ seed and $\mathrm{C}_{3}$ : Only RDF + FYM @5.0 $\left.\mathrm{t} \mathrm{ha}^{-1}\right)$ treatments replicated thrice. Among seed treatments, higher seed cotton yield (2842 $\left.\mathrm{kg} \mathrm{ha}^{-1}\right)$, plant height, number of monopodial and sympodial branches, LAI, LAD, and SPAD chlorophyll meter values were recorded with nano $\mathrm{ZnO}$ seed treatment than seed priming with nano zinc solution and chelated $\mathrm{ZnSO}_{4}$ seed treatment. Among different foliar spray concentrations, foliar application of nano $\mathrm{ZnO} @ 1000$ ppm recorded higher seed cotton yield $\left(2718 \mathrm{~kg} \mathrm{ha}^{-1}\right)$, plant height $(190.1 \mathrm{~cm})$, number of monopodial branches (4.3), sympodial branches (28.6), LAI (3.10), LAD (78.3), and SPAD chlorophyll meter value (41.3) than other concentrations. Among all treatment combinations, seed treatment with nano $\mathrm{ZnO}$ in combination with foliar application of nano ZnO @ 1000 ppm recorded significantly higher seed cotton yield $\left(3221 \mathrm{~kg} \mathrm{ha}^{-1}\right)$ gross returns $\left(₹ 1,56,241 \mathrm{ha}^{-1}\right)$, net returns $\left(₹ 88128 \mathrm{ha}^{-1}\right.$ ) and B:C ratio (2.3) than recommended practices.

\section{Introduction}

Cotton is the most important fiber crop of the world and one of the most widely grown commercial crops in India. The nutrient removal by cotton plant depends on growing conditions and yield potential of the cultivar. On an average rainfed cotton removes $6-7 \mathrm{~kg}$ $\mathrm{N}, 2-2.5 \mathrm{~kg} \mathrm{P}, 7-8 \mathrm{~kg} \mathrm{~K}$ (Venugopalan and Blaise, 2001) and irrigated cotton removes 9- 
10 kg N, 3-4 kg P, 10-12 kg K (Palaniappan and Annadurai, 1995) to produce one quintal seed-cotton yield. Apart from major nutrients, micronutrients also play a vital role in cotton production (Anon., 1995). Essential micronutrients like Zinc, Iron, Manganese, Copper, Boron and Zinc plays an important role in physiology of cotton crop and they are being a part of enzyme system or catalyst in enzymatic reactions. They are required for plant activities such as respiration, meristematic development, chlorophyll formation, photosynthesis, energy system, protein and oil synthesis, gossypol, tannin and phenolic compounds development (Anon., 1995). An analysis of 0.233 million soil samples taken from different states showed that 47 per cent of Indian soils are deficient in Zn (Takkar, 2012).

Emphasis on present day agriculture is to produce more with lesser natural resources like land, water, inputs and man power. Considering the above factors with a growing world population there has been a growing interest to develop such management practices or tools which alone or in combination with other practices could ensure a good yield. For this seed treatment and foliar application with micronutrients are one of the major tools in cotton production.

Seed treatment is like baby care being with the mother (Heydecker and Coolbear, 1977) and it ranges from a basic dressing to coating and pelleting (Krishna and Dubey, 2006). Presently seed treatment by using polymer as coating material along with micronutrients is gaining importance. It is done to control a variety of pests, diseases and to ensure uniform stand establishment by protecting against soil borne pathogens and insects.

To save the cotton crop from nutrient deficiencies, foliar nutrition with different nutrients at particular intervals has a vital role. The advantages of using foliar feeding of plants are quick plant response, small quantity of the nutrient, compensation for the lack of soil fixation, avoiding root uptake problems, increased yield and fiber quality in cotton (Pumisacho and Sherwood, 2002).

Supplying of chemical fertilizers in the form of nanoparticles has recently received considerable attention. Indeed, nanotechnology has provided the feasibility of exploiting nanoscale or nanostructured materials as fertilizer carriers or controlledrelease vectors for building of so-called "smart fertilizer" as new facilities to enhance nutrient use efficiency and reduce costs of environmental protection (Tarafdar et al., 2011).

A Nano fertilizer increases the nutrient use efficiency (NUE) by 3 times and it also provides stress tolerating ability (Valadkhan et al., 2015). Two principal factors cause the properties of nanomaterials to differ significantly from others are materials increased relative surface area and quantum effects. Nanoparticles are atomic or molecular aggregates with at least one dimension between 1 and $100 \mathrm{~nm}$, which can drastically modify their physicochemical properties as compared to the bulk material. Owing to its high surface area to volume size ratio, exhibit significantly novel and improved physical, chemical, and biological properties, phenomena and functions (Lengke et al., 2000).

Due to the significance of zinc element in crop growth and production and their positive role in increasing yield and quality due to application of nano form through seed treatment and foliar spray in cotton. The time and speed for the release of elements coincide and match plant nutritional requirements, thus the plant can absorb maximum amount of nutritional elements and as a consequence, the product yield increases as well. 
However, the studies related to seed treatment and foliar application of nano $\mathrm{ZnO}$ on cotton in India is very meager or seldom nil. Hence the present investigation was carried out to know the impact of seed treated and foliar applied nano zinc and conventional zinc fertilizer on growth, yield and economics of Bt cotton.

\section{Materials and Methods}

A Field experiment was conducted at Main Agricultural Research Station, Dharwad, during kharif 2017-2018. The experiment was laid out in split plot design with three main treatments $\left(\mathrm{S}_{1}\right.$ : seed treatment with chelated $\mathrm{ZnSO}_{4} @ 4 \mathrm{~g} \mathrm{~kg}^{-1}$ seeds, $\mathrm{S}_{2}$ : nano $\mathrm{ZnO} @ 1 \mathrm{~g}$ $\mathrm{kg}^{-1}$ seeds and $\mathrm{S}_{3}$ : seed priming with 1000 ppm nano zinc solution), four sub plot treatments (Foliar application of nano $\mathrm{ZnO}$ @ 500, 750, 1000 and $1250 \mathrm{ppm}$ at square initiation and flowering stage) and three uneven control $\left(\mathrm{C}_{1}\right.$ : RDF + FYM + $0.5 \%$ EDTA $\mathrm{ZnSO}_{4}$ foliar application at square initiation and flowering stage, $\mathrm{C}_{2}: \mathrm{C}_{1}+$ seed treatment with micronutrients $\mathrm{Fe}, \mathrm{Zn}, \mathrm{Mg}$ and

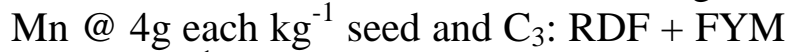
@ $5.0 \mathrm{t} \mathrm{ha}^{-1}$ ) treatments replicated thrice. The hybrid Bt Cotton Superb SP7157 (BG-II) was sown in a plot size of $7.2 \times 5.4 \mathrm{~m}$ for each treatment. Seeds were dibbled as per the specification on $05^{\text {th }}$ July 2017 . Two seeds per hill were dibbled to a depth of $5 \mathrm{~cm}$ on flat bed in $90 \mathrm{~cm}$ rows at $60 \mathrm{~cm}$ distance between plant to plant and Recommended dose of fertilizers (RDF) @ 100:50:50 kg N: $\mathrm{P}_{2} \mathrm{O}_{5}$ : $\mathrm{K}_{2} \mathrm{O} \mathrm{ha}^{-1}+\mathrm{FYM} @ 5.0 \mathrm{t} \mathrm{ha}^{-1}$ was applied commonly to all treatments.

Observations on growth parameters viz., plant height $(\mathrm{cm})$, number of monopodial branches (plant $\left.^{-1}\right)$, number of sympodial branches $\left(\right.$ plant $\left.^{-1}\right)$, leaf area index (LAI), leaf area duration (LAD), and SPAD chlorophyll meter value of cotton were recorded at 60,90, 120, 150 DAS and at harvest stage. Seed cotton yield (3 times picking) in each net plot was harvested separately, weighed and recorded. After complete harvesting, weight of seed cotton obtained at each picking was added with previous pickings. Besides, yield obtained from other five observation plants was also added and recorded as net plot yield. On the basis of seed cotton yield recorded in net plot, the seed cotton yield hectare ${ }^{-1}$ was computed and expressed as seed cotton yield in $\mathrm{kg} \mathrm{ha}^{-1}$. Similarly, stalk yield was worked out by weighing dried stalks per net plot and expressed in $\mathrm{kg} \mathrm{ha}^{-1}$. Further, economical parameters namely gross returns ( $₹ \mathrm{ha}^{-1}$ ) was worked out by multiplying seed cotton yield and stalk yield $\left(\mathrm{kg} \mathrm{ha}^{-1}\right)$ with market price of seed cotton yield ( $₹ \mathrm{~kg}^{-1}$ ) and price of stalk $\left(₹ \mathrm{~kg}^{-1}\right)$. Net returns $\left(₹ \mathrm{ha}^{-1}\right)$ by deducting cost of cultivation (₹ ha ${ }^{-1}$ ) from gross returns and benefit cost ratio (B: C) by dividing gross returns $\left(₹ \mathrm{ha}^{-1}\right)$ by cost of cultivation (₹ $\left.\mathrm{ha}^{-1}\right)$.

\section{Results and Discussion}

\section{Response of cotton for seed treatment}

Higher seed cotton yield of $2842 \mathrm{~kg} \mathrm{ha}^{-1}$ was recorded with seed treatment with nano $\mathrm{ZnO}$ than seed priming with nano zinc solution $\left(2478 \mathrm{~kg} \mathrm{ha}^{-1}\right.$ ) and seed treatment with chelated $\mathrm{ZnSO}_{4}\left(2309 \mathrm{~kg} \mathrm{ha}^{-1}\right)$. The increase in seed cotton yield in seed treatment with nano $\mathrm{ZnO}$ was 14.6 percent over seed priming with nano zinc solution and 23.08 per cent over seed treatment with chelated $\mathrm{ZnSO}_{4}$. Polymeric coating has been investigated to improve germination rate and seedling vigor (Herner, 1986). It was noticed that application of $\mathrm{Zn}$ in the nano form increased the total chlorophyll content in the leaves and IAA production by root. Similar results were obtained by Rathinavel (2015). The higher seed cotton yield from seed treatment with nano $\mathrm{ZnO}$ was attributed to higher seed, lint and stalk yield hectare ${ }^{-1}(7084 \mathrm{~kg})$ than seed 
priming with nano zinc solution $(6725 \mathrm{~kg})$, and seed treatment with chelated $\mathrm{ZnSO}_{4}(6550$ $\mathrm{kg}$ ). Nano $\mathrm{Zn}$ plays a key role in photosynthesis, affecting the activity of enzymes such as carbonic anhydrase and also due to its small size uptake is more (Rengel, 1995), as well as it affects on chlorophyll concentration and stomatal conductance $(\mathrm{Hu}$ and Sparks, 1991).

The photosynthetic parameters were higher with seed treatment with nano $\mathrm{ZnO}$ as compared to other treatments as depicted through higher leaf area index (LAI) and leaf area duration (LAD) at all the growth stages, except at harvesting stage. However, at 90 and 120 DAS, leaf area index was on par with seed priming treatment. Further, the seed treatment with nano $\mathrm{ZnO}$ has more leaf area duration (LAD) as compared to other treatments. LAD is physiological character that decides the rate of growth. The higher LAD might be due to increased nitrogen uptake in nano $\mathrm{ZnO}$ treatment which intern increase auxin activity and production of carbohydrates leading to accelerate meristematic activity at the shoot apex which intern increased leaf area and LAI which resulted in higher LAD (Rathinavel, 2015). Seed treatment with nano $\mathrm{ZnO}$ increased the SPAD chlorophyll meter values.

Numerically higher SPAD chlorophyll meter values were observed at all phenological stages in seed treatment with nano $\mathrm{ZnO}$ as compared to other treatments. Seed treatment with nano $\mathrm{ZnO}$ recorded higher plant height (190.87 cm), number of monopodial branches (4.0) and sympodial branches (29.1).

The presence of nanoscale $\mathrm{ZnO}$ particles has a significant effect on the plant height of Phaseolus vulgaris and Lolium Perenne (Doshi et al., 2008). The presence of $\mathrm{ZnO}$ nano particles increased nutrient uptake in turn increased yield to the extent of 28.3 percent as compared to chelated $\mathrm{ZnSO}_{4}$. Similar trend was reported by Zhu et al., (2008). Among all the treatments, seed treatment with nano $\mathrm{ZnO}$ recorded higher gross returns ( $₹ 1,37,818 \mathrm{ha}^{-1}$ ), net returns ( $₹$ 73,568 $\mathrm{ha}^{-1}$ ) and $\mathrm{B}$ : $\mathrm{C}$ ratio (2.1) than other seed treatments. The increase in economical returns in seed treatment was 14.6, 29.0 and 10.5 per cent over nano $\mathrm{ZnO}$ seed priming and 23.0, 47.0 and 16.6 per cent over seed treatment with chelated $\mathrm{ZnSO}_{4}$, with respect to gross returns, net returns and $\mathrm{B}: \mathrm{C}$ ratio, respectively.

\section{Response of cotton for foliar application of nano $\mathrm{ZnO}$}

Higher seed cotton yield of $2718 \mathrm{~kg} \mathrm{ha}^{-1}$ was recorded with $1000 \mathrm{ppm}$ than other concentrations. The increase in seed cotton yield in 1000 ppm was 6.7, 7.5 and 14.15 per cent higher over 1250, 750 and 500 ppm, respectively. Improvement in yield might be due to the improved growth characters as a result of nano zinc which would have enhanced photosynthesis and other metabolic activities, which lead to increase in cell division and elongation (Hatwar et al., 2003). The higher seed cotton yield in 1000 ppm nano $\mathrm{ZnO}$ was attributed to higher stalk yield hectare $^{-1}(6960 \mathrm{~kg})$ than other concentrations.

The photosynthetic parameters were higher in $1000 \mathrm{ppm}$ as compared to other concentrations as depicted through higher LAI and LAD at 60, 90 and 120 DAS. The chlorophyll content regulates the photosynthetic efficiency. Significantly, higher SPAD chlorophyll meter values were recorded with $1000 \mathrm{ppm}$ nano $\mathrm{ZnO}$ foliar spray at all the phenological stages from 60 DAS to harvest as compared to other treatments. The other parameters, which are responsible for increasing yield, were plant height, monopodial branches and sympodial branches (Table 1). 
Table.1 Plant height, number of monopodial and sympodial branches of Bt cotton at different growth stages as influenced by Nano ZnO seed treatment and foliar application

\begin{tabular}{|c|c|c|c|c|c|c|c|c|c|c|c|c|}
\hline \multirow[t]{2}{*}{ Treatments } & \multicolumn{3}{|c|}{ Plant height (cm) } & \multicolumn{4}{|c|}{ No. of monopodial branches $\left(\right.$ plant $\left.^{-1}\right)$} & \multicolumn{5}{|c|}{ No. of sympodial branches $\left(\right.$ plant $\left.^{-1}\right)$} \\
\hline & 60 DAS & 120 DAS & At harvest & 60 DAS & 90 DAS & 120DAS & 150 DAS & 60 DAS & 90 DAS & 120 DAS & 150 DAS & \\
\hline $\mathbf{S}_{1}$ : Chelated $\mathrm{ZnSO}_{4}\left(4 \mathrm{~g} \mathrm{~kg}^{-1}\right.$ seeds in $8 \mathrm{ml}$ polymer $)$ & 83.5 & 169.70 & 186.4 & 2.4 & 3.6 & 3.7 & 3.7 & 12.0 & 16.9 & 23.7 & 25.9 & \\
\hline $\mathbf{S}_{2}:$ Nano $\mathrm{ZnO}\left(1 \mathrm{~g} \mathrm{~kg}^{-1}\right.$ seeds in $8 \mathrm{ml}$ polymer $)$ & 88.8 & 173.9 & 190.87 & 2.8 & 4.0 & 4.0 & 4.0 & 14.5 & 20.0 & 26.8 & 29.1 & \\
\hline $\mathbf{S}_{3}$ : Nano Zinc $1000 \mathrm{ppm}$ of 8 hours soaking (Seed priming) & 85.3 & 170.8 & 187.7 & 2.7 & 3.9 & 3.9 & 3.9 & 13.2 & 17.8 & 25.0 & 27.3 & \\
\hline S.Em \pm & 0.37 & 0.40 & 0.45 & $\mathbf{0 . 0 3}$ & $\mathbf{0 . 0 4}$ & 0.06 & 0.06 & 0.25 & 0.27 & 0.29 & 0.39 & \\
\hline C.D. $(P=0.05)$ & 1.11 & 1.2 & 1.41 & 0.09 & $\mathbf{0 . 1 2}$ & 0.18 & $\mathbf{0 . 1 8}$ & 0.75 & $\mathbf{0 . 8 1}$ & 0.87 & 1.17 & \\
\hline \multicolumn{12}{|l|}{ Sub plots: Foliar application of Nano $\mathrm{ZnO}$. (F) } & \\
\hline $\mathbf{F}_{1}: 500 \quad \mathrm{ppm}$ at square initiation and flowering stage & 83.9 & 169.8 & 186.7 & 2.5 & 3.6 & 3.7 & 3.7 & 12.6 & 17.0 & 23.8 & 26.1 & \\
\hline $\mathbf{F}_{2}: 750 \quad \mathrm{ppm}$ at square initiation and flowering stage & 85.3 & 171.3 & 188.2 & 2.6 & 3.8 & 3.8 & 3.8 & 13.0 & 18.2 & 25.0 & 27.3 & \\
\hline $\mathbf{F}_{3}: 1000 \mathrm{ppm}$ at square initiation and flowering stage & 87.6 & 173.2 & 190.1 & 2.8 & 4.0 & 4.0 & 4.0 & 13.8 & 19.4 & 26.3 & 28.6 & \\
\hline $\mathbf{F}_{4}: 1250 \mathrm{ppm}$ at square initiation and flowering stage & 86.7 & 171.6 & 188.4 & 2.7 & 3.9 & 4.0 & 4.0 & 13.5 & 18.2 & 25.5 & 27.7 & \\
\hline S.Em \pm & 0.25 & $\mathbf{0 . 3 0}$ & 0.41 & 0.01 & $\mathbf{0 . 0 2}$ & $\mathbf{0 . 0 3}$ & $\mathbf{0 . 0 3}$ & 0.21 & 0.22 & 0.23 & $\mathbf{0 . 3 3}$ & \\
\hline C.D. $(P=0.05)$ & 0.75 & 0.9 & 1.25 & $\mathbf{0 . 0 3}$ & 0.06 & 0.09 & 0.09 & 0.63 & 0.66 & 0.69 & 0.99 & \\
\hline \multicolumn{13}{|l|}{ Interaction: (SXF) } \\
\hline $\mathbf{S}_{1} \mathbf{X} \mathbf{F}_{1}:$ & 80.4 & 168.8 & 185.7 & 2.3 & 3.4 & 3.5 & 3.5 & 11.7 & 16.6 & 23.4 & 25.6 & \\
\hline$S_{1} \times F_{2}:$ & 83.0 & 168.9 & 185.8 & 2.3 & 3.5 & 3.6 & 3.6 & 11.9 & 16.9 & 23.7 & 25.9 & \\
\hline$S_{1} X F_{3}:$ & 84.2 & 169.1 & 186.0 & 2.5 & 3.7 & 3.7 & 3.7 & 12.0 & 16.9 & 23.7 & 26.0 & \\
\hline$S_{1} X F_{4}:$ & 86.4 & 172.0 & 188.4 & 2.6 & 3.8 & 3.9 & 3.9 & 12.5 & 17.1 & 23.9 & 26.1 & \\
\hline$S_{2} \times F_{1}:$ & 87.0 & 171.6 & 188.5 & 2.5 & 3.7 & 3.8 & 3.8 & 13.2 & 18.4 & 25.2 & 27.5 & \\
\hline $\mathbf{S}_{2} \times F_{2}$ & 88.0 & 173.0 & 189.9 & 2.7 & 3.9 & 3.9 & 3.9 & 14.1 & 19.0 & 25.8 & 28.1 & \\
\hline$S_{2} X F_{3}$ & 93.2 & 178.2 & 195.1 & 3.0 & 4.2 & 4.3 & 4.3 & 16.1 & 22.2 & 29.0 & 31.3 & \\
\hline$S_{2} \times F_{4}:$ & 87.2 & 172.8 & 190.0 & 2.9 & 4.0 & 4.1 & 4.1 & 14.6 & 20.3 & 27.1 & 29.4 & \\
\hline$S_{3} \times F_{1}:$ & 84.4 & 169.0 & 185.9 & 2.6 & 3.7 & 3.8 & 3.8 & 13.0 & 16.1 & 22.9 & 25.2 & \\
\hline$S_{3} \times F_{2}$ & 84.8 & 171.9 & 188.8 & 2.7 & 3.9 & 4.0 & 4.0 & 13.1 & 18.8 & 25.6 & 27.9 & \\
\hline$S_{3} X F_{3}:$ & 85.4 & 172.2 & 189.1 & 2.8 & 4.0 & 4.1 & 4.1 & 13.2 & 19.1 & 26.2 & 28.5 & \\
\hline$S_{3} X F_{4}:$ & 86.4 & 170.0 & 186.9 & 2.6 & 3.8 & 3.9 & 3.9 & 13.5 & 17.2 & 25.4 & 27.7 & \\
\hline S.Em \pm & 0.72 & 0.75 & 0.80 & 0.06 & 0.08 & 0.09 & 0.09 & 0.40 & 0.45 & 0.56 & 0.57 & \\
\hline C.D. $(\mathbf{P}=\mathbf{0 . 0 5})$ & 2.16 & 2.25 & 2.40 & 0.18 & 0.24 & 0.27 & 0.27 & 1.20 & 1.35 & 1.68 & 1.71 & \\
\hline \multicolumn{12}{|l|}{ Control plots: $(\mathrm{C})$} & \\
\hline 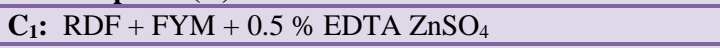 & 72.8 & 138.4 & 152.8 & 2.1 & 3.2 & 3.3 & 3.3 & 10.6 & 15.4 & 22.2 & 24.5 & \\
\hline $\mathbf{C}_{2}:\left(\mathrm{C}_{1}+\right.$ seed treatment with micronutrients $)$ & 79.1 & 143.1 & 160.0 & 2.1 & 3.3 & 3.4 & 3.4 & 10.8 & 16.2 & 23.0 & 24.9 & \\
\hline $\mathbf{C}_{3}$ : RDF only & 74.7 & 130.5 & 148.0 & 1.8 & 2.9 & 3.1 & 3.1 & 10.2 & 15.2 & 21.1 & 23.7 & \\
\hline S.Em \pm & 2.01 & 4.9 & 5.1 & 0.08 & 0.10 & 0.15 & 0.15 & 0.44 & 0.60 & 0.73 & 0.79 & \\
\hline C.D. $(P=0.05)$ & 6.03 & 14.3 & 15.5 & 0.23 & 0.32 & 0.36 & 0.36 & 1.33 & 1.80 & 2.19 & 2.37 & \\
\hline
\end{tabular}

DAS: Days after sowing. 
Foliar spray with nano ZnO @1000 ppm recorded higher plant height (93.2, 178.2 and $195.1 \mathrm{~cm}$, at 60, 120 DAS and $\mathrm{AH}$, respectively). Similar trend was observed in monopodial branches $(2.8,4.0,4.0$ and 4.0 , at 60, 90, 120 and 150 DAS, respectively) and sympodial branches (13.8, 19.4, 26.3 and 28.6, respectively at 60, 90, 120 and 150 DAS) than other concentrations. Among all foliar sprays, nano $\mathrm{ZnO} @ 1000$ ppm recorded higher gross returns ( $₹ 131817 \mathrm{ha}^{-1}$ ), net returns ( $₹$ 66,606 $\mathrm{ha}^{-1}$ ) and $\mathrm{B}$ : C ratio (2.0). The increase in economical returns like GR, NR and B:C ratio in foliar application of nano ZnO @1000 ppm was 6.7, 14.4 and 5.2 per cent over 1250 ppm and 7.5, 10.0 and 5.2 per cent over 750 ppm 14.15, 20.17, 5.2 per cent over 500 ppm, respectively).

\section{Interaction effect of seed treatment and foliar application of nano zinc}

In the present investigation, different foliar spray concentration with chelated $\mathrm{ZnSO}_{4}$ seed treatment, did not affect seed cotton yield significantly, similar trend was followed for all growth and yield attributing characters. Seed treatment with nano $\mathrm{ZnO}$ recorded higher seed cotton yield with 1000 ppm foliar spray (3221 kg ha ${ }^{-1}$ ) than other treatment combinations. Similar trend was followed in all growth and yield attributing characters.

Among seed treatments with same or different foliar spray techniques, significantly higher cotton yield (3221 kg ha-1) was obtained in seed treatment with nano $\mathrm{ZnO}$ with 1000 ppm foliar spray than other treatment combinations. Lower yield was recorded with treatment combination of seed treatment with chelated $\mathrm{ZnSO}_{4}$ with 500 ppm foliar spray (2284 $\mathrm{kg} \mathrm{ha}^{-1}$ ) than other concentrations. When compared to recommended practices the best treatment Nano $\mathrm{ZnO}$ seed treatment with foliar application of Nano ZnO @ 1000 ppm recorded higher seed cotton yield. The per cent increase in yield was to the tune of
53.6, 61.29 and $66.45 \%$ over recommended package of practice, $\mathrm{RDF}+0.5 \%$ EDTA foliar spray and only RDF, respectively.

In the present investigation, between different foliar sprays at same treatment did not influence the economical parameters for chelated $\mathrm{ZnSO}_{4}$ seed treatment. However, the interaction of seed treatment with Nano $\mathrm{ZnO}$ with foliar application of Nano $\mathrm{ZnO}$ recorded significantly higher gross returns ( $₹$ 1,56,241 $\mathrm{ha}^{-1}$ ), net returns ( $₹ 88128 \mathrm{ha}^{-1}$ ) and B:C ratio (2.3) than other combinations. Seed priming with Nano $\mathrm{ZnO}$ along with foliar application of Nano ZnO @ 1000 ppm recorded higher gross returns (₹ 1,27,191 ha ${ }^{-1}$ ). However, 750 ppm was on par with 1000 ppm concentration. Among all treatment combinations, seed treatment with Nano $\mathrm{ZnO}$ with foliar application of Nano $\mathrm{ZnO}$ recorded significantly higher gross returns, net returns and $\mathrm{B}: \mathrm{C}$ ratio than recommended practices. The percent increase in Gross returns, net returns and $\mathrm{B}: \mathrm{C}$ ratio was 53.63, 94.2 and 27.7 per cent over RPP, respectively. This was evidenced by Singh et al., (2013) and Singh and Bhati (2013).

In conclusion, application of micronutrient zinc in the form of Nano particles performed better than normal form of fertilizers. Seed treatment and foliar application of Nano $\mathrm{ZnO}$ had significant influence on increasing seed cotton yield than normal recommended fertilizers. In the present study, seed treatment with Nano $\mathrm{ZnO} @ 1 \mathrm{~g} \mathrm{~kg}^{-1}$ seeds in $8 \mathrm{ml}$ polymer along with foliar application of Nano $\mathrm{ZnO} @ 1000$ ppm at square initiation and flowering stage was found to be optimum for cotton crop for obtaining better growth, seed cotton yield, and economical returns.

\section{References}

Anonymous, 1995, Textile exchange and fibre production report. Cotton production techonology, Nagpur, pp. 46-49. 
Doshi, A., Biswas, A. K. and Kundu, S., 2008, Nano-fertilizer-a new dimension in agriculture. Indian J. Fertilizers., 6(8): 2224.

Hatware, M., Girgis, H., Hamed, R. and Osman, M., 2003, Testing the equality of growth curves of independent populations with application of nano particles. American $J$. Biostatistics., 1: 46-61.

Herner, M., Imran, M. and Rehim, A., 1986, Zinc fertilization approaches for agronomic biofortification and estimated human bioavailability of zinc in maize grain. Archives Agron. Soil Sci., 63(1):106116.

Heydecker, W. and Coolbear, P., 1977, Seed treatments for improved performance survey and attempted prognosis. Seed Sci. Technol., 5: 353-425.

Hu, H. and Sparks, D., 1991, Zinc deficiency inhibits reproductive development in "Stuart" pecan Hort. Sci., 25: 1392-1396.

Krishna and Dubey, 2006, Insecticide and fungicide and micronutrient seed treatment. Seed Sci. Techonol., 16(3): 72-75

Lengke, F.M., Fleet E. M. and Southam, G., 2000, Biosynthesis of silver nanoparticles by filamentous cyanobacteria a from a silver nitrate complex. Langmuir, 23: 2694-2699.

Palaniappan, R and Annadurai, 1995, Effect of organic and modern method of cotton cultivation on soil nutrient status. Comm. Soil Sci. Pl. Anal., 5(9-10): 1247-1261.

Pumisacho, M. and Sherwood, S., 2002, El cultivo de la papa en Ecuador. Instituto Nacional de Investigaciones Agropecuarias (INAP), $58^{\text {th }}$ Annu. Meet., International Potato Center (CIP), Quito.

Rathinavel, L., Alan, R. G., Eruva, N. and Haris,
L. S., 2015, Role of superoxide dismutase's in controlling oxidative stress in plants. $J$. Exp. Bot., 53(372): 1331-1341.

Rengel, Z., Khan, H. R. and Mcdonald, G. K., 1995, Zinc fertilization improves water use efficiency, grain yield and seed $\mathrm{Zn}$ content in chickpea. Pl. Soil., 249: 389-400.

Singh, K. and Bhati., 2013, Determination of critical level of zinc in non-calcareous soils for predicting response of cotton to applied zinc. Fert. Res., 8: 97-100.

Singh, K., Ramesh, K. and Tarun, O., 2013, Determination of critical limit of zinc in soils in India for predicting response of cotton to nano zinc application. Field Crop Res., 90: 143-149.

Takkar, P.N. 2012, Micronutrient research and sustainable agricultural productivity in India. J. Indian Soc. Soil Sci., 44: 562-581.

Tarafdar, J. C., Raliya, R. and Rathore, I., 2011, Microbial synthesis of zinc nanoparticles and its effect on growth and yield of pearl millet. J. Bio. Nanosci., 6: 84-89.

Valadkhan, M., Mohammadi, K. and Nezhad, M. T. K., 2015, Effect of priming and foliar application of nanoparticles on agronomic traits of chickpea. Bio. Forum Int. J., 7(2): 599-602.

Venugopalan, S. and Blaise, G., 2001. Comparative evaluation of organic and nonorganic cotton (Gossypium hirsutum) production systems. Indian J. Agric. Sci., 80 (4): 287-292.

Zhu, H., Zhang X. and Sun C., 2008, Characteristics of micro nutrients uptake by rape plants and methods of $\mathrm{B}$ and $\mathrm{Zn}$ application. Oil Crops of China., 18(2): 5961.

\section{How to cite this article:}

Pruthvi Raj, N. and Chandrashekara, C.P. 2019. Nano Zinc Seed Treatment and Foliar Application on Growth, Yield and Economics of Bt Cotton (Gossypium hirsutum L.). Int.J.Curr.Microbiol.App.Sci. 8(08): 1624-1630. doi: https://doi.org/10.20546/ijcmas.2019.808.192 